\title{
EFEITO DA PRESENÇA DE RUFIÕES SOBRE A PRIMEIRA TEMPORADA REPRODUTIVA DE NOVILHAS DE CORTE*
}

\author{
GUILHERME FIGUEIREDO DE SOUZA
}

Ricardo Macedo Gregory (Orientador - UFRGS)

Banca Examinadora:

Carlos Antônio Mondino Silva UFSM

José Luiz Rodrigues UFRGS

Rodrigo Costa Mattos UFRGS

Rui Fernando Felix Lopes UFRGS

O efeito da presença do touro rufião (touro com desvio lateral de pênis) e da vaca rufião (vaca androgenizada), ambos adaptados com buçal marcador "Chin Ball", foi estudado durante 2 temporadas reprodutivas realizadas nos meses de dezembro a fevereiro de 1999/2000 (período 1) e 2000/2001 (período 2). Durante o período de 73 dias de experimento para ambas temporadas, objetivou-se verificar se os rufiões: 1 . possibilitariam incremento na detecção de estro das novilhas; 2. determinariam antecipação dos dias para observação de estro; 3. aumento nas taxas de prenhez. Utilizou-se para cada experimento um total de 60 novilhas cruzadas de genótipo, predominantemente, Bos taurus, com idade entre 1 a 2,5 anos. Estas novilhas foram divididas aleatóriamente em 3 grupos, de 20 novilhas, homogêneos para as médias de peso, condição corporal e idade. Assim teve-se o grupo $1 \mathrm{com} \mathrm{n}=20$ mais a presença da vaca androgenizada, o grupo 2 com $\mathrm{n}=20$ mais a presença do touro com desvio lateral de pênis e o grupo $3 \mathrm{com} n=20 \mathrm{sem}$ a presença de rufião. Todos os grupos foram controlados para identificação de estro através da observação visual de estro pelo técnico com 2 observações diárias de estro durante 30 minutos cada, por grupo. Durante o período experimental forneceu-se suplementação de ração à campo, com um GMD total aproximado de $0,95 \mathrm{~kg}$. Constatou-se que o número de animais em estro e as taxas de prenhez não diferiram entre os grupos ( $p>0,05)$, durante as duas temporadas em que realizou-se o experimento. Verificou-se também que o número de dias para detecção de estro foi significativamente menor no grupo 2 em relação ao $1(p=0,05)$, sendo que o grupo 3 não diferiu entre ambos ( $p>0,05)$, durante o experimento. Conclui-se que o touro rufião, determinou resultados bioestimulatórios mais significativos quanto à antecipação da detecção de estro em relação à vaca androgenizada do presente trabalho. Entretanto nenhum dos grupos diferiu em termos de resultados para índice de detecção de estro ou taxas de prenhez.

Descritores: detecção de estro, bioestimulação, fertilidade, novilhas de corte.

Apresentada: 11 setembro 2001

* Dissertação de Mestrado n.314 (Especialidade: Fisiopatologia da Reprodução Animal). 60f. Programa de Pós-Graduação em Ciências Veterinárias da Faculdade de Veterinária, Porto Alegre - UFRGS. CORRESPONDÊNCIA: G.F. Souza [e-mail: guilhermepgvet@eudoramail.com]. 


\title{
EFFECT OF THE PRESENCE OF TEASING BULLS/COWS ON THE FIRST BREEDING SEASON OF BEEF HEIFERS**
}

\author{
GUILHERME FIGUEIREDO DE SOUZA \\ Ricardo Macedo Gregory (Adviser - UFRGS)
}

$\begin{array}{ll}\text { Committee: } & \\ \text { Carlos Antônio Mondino Silva } & \text { UFSM } \\ \text { José Luiz Rodrigues } & \text { UFRGS } \\ \text { Rodrigo Costa Mattos } & \text { UFRGS } \\ \text { Rui Fernando Felix Lopes } & \text { UFRGS }\end{array}$

The effect of the presence of a teasing bull (bull with lateral deviation of the penis) and of the teasing cow (androgenized cow), both adapted with a "Chin Ball" halter, was studied during 2 breeding seasons in the months of december to february 1999/2000 (period 1) e 2000/2001 (period 2). During the 73 days period of the experiment in both seasons, the aim was to verify if the teasers: 1 . Would allow a better estrus detection; 2 . Would determinate the antecipation of days for estrus observation; 3. Would increase pregnancy rates. For each experiment were used 60 cross-breed heifers, predominantly, Bos taurus, with ages between 1 and 2,5 years. The heifers were randomly divided into 3 groups, with 20 heifers each, with the same weight, age and body condition score. So the groups were: $\mathrm{G} 1, \mathrm{n}=20$ plus the androgenized cow, $\mathrm{G} 2, \mathrm{n}=20$ plus the teasing bull and $\mathrm{G} 3, \mathrm{n}=20$ without any teaser. All groups were watched for estrus detection with two daily observations of 30 minutes each, per group. During the experimental period the heifers received concentrated food on the field, with a total GMD approximately $0,95 \mathrm{~kg}$. It was seen that the number of animals in estrus and pregnancy rates did not have difference between groups ( $p>0,05)$, during both seasons of the experiment. Also, the number of days to estrus detection was significantly lower on Group 2 in relation to Group $1(\mathrm{p}=0,05)$, and Group 3 had no difference from any of them $(p>0,05)$. It can be concluded that the teasing bull had more significant bioestimulating results in what concerns to antecipation of estrus detection in relation to the androgenized cow. However, none of the groups had difference in estrus detection and pregnancy rates.

Key words: estrus detection, biostimulation, fertility, beef heifers.

Presented: 11 september 2001

\footnotetext{
** Master's Thesis no.314 (Field: Theriogenology). 60p. Postgraduate Program in Veterinary Sciences, Faculty of Veterinary Medicine, Porto Alegre - Federal University of Rio Grande do Sul (UFRGS)/Brazil. CORRESPONDENCE: G.F. Souza [e-mail: guilhermepgvet@eudoramail.com].
} 